\title{
Identification and characterization of plant growth promoting endophytic bacteria
}

\section{Identyfikacja i charakterystyka bakterii endofitycznych wykazujących cechy promujące wzrost roślin}

\author{
Krzysztof Krawczyk ${ }^{1}{ }^{*}$, Agnieszka Zwolińska ${ }^{1}$, Joanna Kamasa ${ }^{1}$, \\ Anna Maćkowiak-Sochacka ${ }^{1}$, Sebastian Przemieniecki ${ }^{2}$
}

\begin{abstract}
Summary
Endophytic bacteria colonizing plant tissues can play an important role in biotechnology through their plant growth promoting traits. Here we tested endophytic bacterial isolates obtained from the following host plants: maize (Zea mays L.), soy (Glicyne sp. Wilt), rape (Brassica napus L.), wheat (Triticum aestivum L.), poinsettia (Euphorbia pulcherrima Willd. ex Klotzsch), calla (Zantedeschia sp. Spreng), geranium (Pelargonium sp. L’Her), rose (Rosa sp. L.), onion (Allium cepa L.), pea (Pisum sativum L.), cauliflower (Brassica oleracea L.) and cucumber (Cucumis L.). Growth promoting traits of the isolates were first examined on microbiological media. Next that exhibited the desired properties were identified using BIOLOG GEN III system. In general we obtained and tested 109 bacterial isolates. The performed tests revealed that $63 \%$ of examined isolates were able to dissolve inorganic phosphates, further $49 \%$ showed ability to protease production and $39 \%$ to lipase production. Another part (10\%) of tested isolates showed cellulase and pyoverdine production ability.
\end{abstract}

Key words: plant growth promoting; identification; endophytes; testing

\section{Streszczenie}

Endofityczne bakterie żyjące $w$ tkankach roślin mogą odegrać znaczącą rolę w biotechnologii poprzez wspomaganie wzrostu roślin, jako tzw. PGPB (Plant Growth-Promoting Bacteria). Badano izolaty bakteryjne pozyskane z tkanek roślin: (a) uprawnych: kukurydzy (Zea mays L.), soi (Glicyne sp. Wilt), rzepaku (Brassica napus L.), pszenicy (Triticum aestivum L.); (b) roślin ozdobnych: poinsecji (Euphorbia pulcherrima Willd. ex Klotzsch), kalii (Zantedeschia sp. Spreng), pelargonii (Pelargonium sp. L’Her), róży (Rosa sp. L.) oraz (c) roślin ogrodniczych: cebuli (Allium cepa L.), grochu (Pisum sativum L.), kalafiora (Brassica oleracea L.) i ogórka (Cucumis L.). Otrzymane izolaty bakteryjne badano na pożywkach mikrobiologicznych, w celu sprawdzenia czy wykazują one cechy biochemiczne, wspomagające wzrost roślin. Następnie, wybrane izolaty bakteryjne wykazujące pożądane cechy identyfikowano przy użyciu systemu BIOLOG GEN III. Ogółem pozyskano i przebadano 109 izolatów bakterii. Na podstawie przeprowadzonych testów wykazano, że 63\% badanych izolatów ma zdolność do rozpuszczania fosforanów nieorganicznych, kolejne 49\% wykazuje zdolność do produkcji proteazy oraz lipazy (39\%). Część (10\%) badanych izolatów wykazywało zdolność do wytwarzania celulazy i pyowerdyny.

Słowa kluczowe: promowanie wzrostu roślin; identyfikacja; endofity; badanie

\footnotetext{
Instytut Ochrony Roślin - Państwowy Instytut Badawczy

Zakład Wirusologii i Bakteriologii

Władysława Węgorka 20, 60-318 Poznań

${ }^{2}$ Uniwersytet Warmińsko-Mazurski w Olsztynie

Katedra Entomologii, Fitopatologii i Diagnostyki Molekularnej

Prawocheńskiego 17, 10-721 Olsztyn

*corresponding author: k.krawczyk@iorpib.poznan.pl
} 


\section{Wstęp / Introduction}

W ostatnich latach coraz popularniejsze staje się stosowanie w rolnictwie biopreparatów, czyli substancji zawierających żywe organizmy lub odpowiednio przygotowane produkty ich metabolizmu. Niezbędne jest lepsze poznanie i naukowe wyjaśnienie mechanizmów leżących u podstaw ich zastosowania. Wzrost znaczenia stosowania metod biologicznych w rolnictwie w ostatniej dekadzie jest wynikiem działania czynników, takich jak: rosnąca populacja ludzka, zwiększające się zanieczyszczenie środowiska czy dramatycznie zmniejszająca się powierzchnia upraw pod produkcję żywności, co może w przyszłości prowadzić do jej niedoborów na skalę światową. Dlatego tak duże znaczenie ma obecnie problem zwiększenia wydajności produkcji rolnej w kolejnych kilku dekadach. Cel ten może zostać osiągnięty m.in. poprzez upowszechnienie w rolnictwie bardziej zrównoważonych i przyjaznych dla środowiska metod integrowanej ochrony roślin. Jedną $\mathrm{z}$ tych metod jest wykorzystanie bakterii wspomagających (promujących) wzrost roślin (Plant Growth Promoting Bacteria - PGPB).

Pojęciem „bakterie promujące wzrost roślin” określamy wszystkie grupy bakterii, które poprzez wybraną cechę lub cechy swojego metabolizmu, korzystnie wpływają na wzrost i rozwój roślin. Należą tutaj następujące grupy organizmów: bakterie wolnożyjące, specyficzne symbionty (np. Rhizobium sp. lub Frankia sp.), bakteryjne endofity, kolonizujące część lub całość tkanki roślinnej gospodarza oraz cyjanobakterie (Glick 2012).

PGPB są szeroko rozpowszechnioną grupą bakterii. Są powiązane $\mathrm{z}$ wieloma, jeśli nie $\mathrm{z}$ wszystkimi, gatunkami roślin i występują powszechnie (Compant i wsp. 2005). Niektóre $\mathrm{z}$ nich mogą przenikać do wnętrza korzenia i dawać początek nowej populacji endofitów (Compant i wsp. 2005). Wiele spośród nich ma zdolność do przenikania endodermy, przechodząc z kory korzeniowej do systemu naczyniowego, by następnie rozwijać się jako endofity $\mathrm{w}$ łodydze, liściach, bulwach i innych organach (Gray i Smith 2005). Rozmiar kolonizacji świadczy o zdolności tych bakterii do selektywnej adaptacji w zmiennych niszach ekologicznych. Konsekwencją tej adaptacji może być wytworzenie wzajemnych powiązań i zależności między bakterią a gospodarzem opartych na wspólnych korzyściach. PGPB są wolno żyjącymi bakteriami bytującymi głównie na powierzchni korzeni roślinnych lub w strefie przykorzeniowej, korzystającymi z uwalnianych przez roślinę składników odżywczych (Glick 1995). Występują one powszechnie w środowisku naturalnym wraz z innymi bakteriami. Najwięcej bakterii znajduje się w glebie uprawnej (do głębokości około $30 \mathrm{~cm}$ ). Warstwa gleby uprawnej o głębokości około $30 \mathrm{~cm}$ i powierzchni jednego hektara może zawierać od kilkudziesięciu kilogramów do nawet kilku ton masy bakteryjnej. W głębszych warstwach gleby ilość bakterii maleje (Acea i wsp. 1988). Średnia ilość mikroorganizmów w glebie szacowana jest na $10^{8}-10^{9}$ komórek na gram gleby, z czego tylko około 1-2\% daje się hodować na pożywkach sztucznych, w warunkach laboratoryjnych (Acea i wsp.
1988). Wiadomo też, że w glebach zanieczyszczonych liczba bakterii może spaść do około $10^{4}$ komórek na gram. Rozmieszczenie bakterii w glebie nie jest równomierne. Większa ich koncentracja występuje w pobliżu korzeni roślin, w ryzosferze lub ryzoplanie (Rovira 1965; Van Overbeek i Van Elsas 1995).

Celem pracy była izolacja bakterii z różnych gospodarzy roślinnych, ich charakterystyka pod kątem występowania cech biochemicznych promujących wzrost roślin oraz wstępna identyfikacja biochemiczna wybranych szczepów bakteryjnych.

\section{Materiały i metody / Materials and methods}

Materiał badawczy stanowiły izolaty bakterii pochodzące z tkanek roślin: (a) uprawnych: kukurydzy (Zea mays L.), soi (Glicyne sp. Wilt), rzepaku (Brassica napus L.), pszenicy (Triticum aestivum L.); (b) roślin ozdobnych: poinsecji (Euphorbia pulcherrima Willd. ex Klotzsch), kalii (Zantedeschia sp. Spreng), pelargonii (Pelargonium sp. L`Her), róży (Rosa sp. L.) oraz (c) roślin ogrodniczych: cebuli (Allium cepa L.), grochu (Pisum sativum L.), kalafiora (Brassica oleracea L.) i ogórka (Cucumis L.). Pozyskane izolaty bakteryjne badano na pożywkach mikrobiologicznych, w celu sprawdzenia czy wykazują one cechy opisywane w literaturze naukowej jako wspomagające wzrost roślin. W dalszej kolejności, izolaty bakteryjne wykazujące pożądane cechy oraz niektóre, wybrane losowo, identyfikowano przy pomocy metody biochemiczno-fizjologicznej, przy użyciu systemu BIOLOG GEN III (BIOLOG Inc. Hayward, CA). Sposób postępowania podczas każdego $\mathrm{z}$ etapów pracy przedstawiony został poniżej, a dane charakteryzujące zebrane izolaty bakteryjne przedstawiono $\mathrm{w}$ tabeli 1 .

\section{Izolacja bakterii z roślin}

$\mathrm{Z}$ materiału roślinnego pozyskiwano izolaty bakteryjne niebytujące na powierzchni roślin i będące endofitami (tab. 1). W tym celu od roślin oddzielano liście, łodygę i korzenie. Części roślin przy pomocy sterylnej wody destylowanej (SWD) oczyszczano z ziemi i pyłu, po czym każdy $\mathrm{z}$ organów wkładano do osobnej kolbki z $1 \%$ roztworem Tween 80 i wytrząsano przez 20 minut przy $100 \mathrm{obr} . / \mathrm{min}$. Części roślin dezynfekowano powierzchniowo zanurzając je kolejno w roztworach: 10\% nadtlenku wodoru $\left(\mathrm{H}_{2} \mathrm{O}_{2}\right), 70 \%$ alkoholu etylowego $\left(\mathrm{C}_{2} \mathrm{H}_{5} \mathrm{OH}\right)$ i $5 \%$ podchlorynu sodu $(\mathrm{NaOCl})$. Następnie trzykrotnie płukano w SWD i homogenizowano w moździerzach zawierających $9 \mathrm{ml}$ sterylnej soli fizjologicznej. Z otrzymanego homogenizatu przygotowano szereg rozcieńczeń dziesiętnych i z rozcieńczeń: $10^{-2}$ i $10^{-4}$ wykonano posiew $0,1 \mathrm{ml}$ na płytki Petriego $\mathrm{z}$ : agarem odżywczym, rozcieńczonym agarem odżywczym (w stosunku 1:10) oraz agarem odżywczym z $1 \mathrm{mM}$ chlorkiem kadmu $\left(\mathrm{CdCl}_{2}\right)$. Inokulum rozprowadzono głaszczką po powierzchni tych podłoży i poddano inkubacji $\mathrm{w}$ temperaturze $25^{\circ} \mathrm{C}$ przez 48 godzin. Przeprowadzono kontrolę sterylizacji poprzez wykonanie posiewu $0,1 \mathrm{ml}$ wody $\mathrm{z}$ ostatniego płukania każdego organu roślinnego na płytki Petriego z agarem odżywczym. 


\section{Charakterystyka biochemiczna}

W celu sprawdzenia czystości kultur uzyskanych izolatów bakteryjnych, oprócz posiewów redukcyjnych na agarze tryptozowo-sojowym (Tryptic Soy Agar), wykonano również barwienie Grama według Reed. Po wybarwieniu kolonii, oceniono ich czystość w mikroskopie optycznym, przeglądając preparaty przy powiększeniu $100 \times$ z użyciem olejku immersyjnego.

Czyste kultury badanych izolatów bakteryjnych sprawdzono pod kątem wykazywania przez nie cech promujących wzrost roślin. Badano następujące cechy biochemiczne:

- produkcja celulazy na pożywce CMC (carboxymethylcellulose sodium salt medium) (Hankin i Anagnostakis 1997),

- rozpuszczalność fosforanów na podłożu PVK (Pikovskaya`s medium) (Sharma i wsp. 2011),

- wytwarzanie sideroforów na pożywce CAS (chrome azurol S medium) (Ghodsalavi i wsp. 2013),

- wytwarzanie pyowerdyny, fluorescencyjnego sideroforu u bakterii rodzaju Pseudomonas (SM) (succinate medium) (Ghodsalavi i wsp. 2013),

- wytwarzanie lipazy (LP) (lipase production medium) (Ghodsalavi i wsp. 2013),

- wytwarzanie proteazy (SMA) (skim milk agar) (Ghodsalavi i wsp. 2013).

Wszystkie pożywki przygotowano zgodnie z zaleceniami literaturowymi, po czym autoklawowano w temperaturze $121^{\circ} \mathrm{C}$ przez 20 minut, ostudzono i rozlano na płytki Petriego do wystygnięcia i zestalenia. Po inokulacji bakteriami, każdą pożywkę inkubowano w temperaturze $27^{\circ} \mathrm{C}$ przez 48 godzin, z wyjątkiem pożywki PVK, która inkubowano przez 7 dni. Po inkubacji, wyniki badania dla każdego badanego izolatu bakteryjnego zapisywano w 5-punktowej skali: 0-4, gdzie liczby: 0, 1, 2, 3, 4- oznaczają kolejno: brak reakcji, niskie, średnie, wysokie i bardzo wysokie nasilenie obserwowanej reakcji biochemicznej. Wyniki przedstawiono w tabeli 1.

\section{Identyfikacja bakterii}

Czyste kultury bakterii identyfikowano metodą biochemiczno-fizjologiczną, przy pomocy systemu BIOLOG GEN III (BIOLOG Inc. Hayward, CA), postępując ściśle według wskazówek producenta. System BIOLOG jest to gotowy zestaw zawierający sproszkowane podłoża i służący do identyfikacji bakterii Gram-dodatnich i Gramujemnych. System ten umożliwia jednoczesną analizę 95 cech biochemicznych. Na plastikowej płytce zawartych jest 96 studzienek, z czego 95 zawiera sproszkowaną pożywkę zawierającą dane źródło węgla dla bakterii. Ostatnia studzienka nie zawiera pożywki i jest kontrolą ujemną. W trakcie badania studzienki napełnia się zawiesiną bakteryjną danego izolatu o ściśle określonej gęstości i inkubuje przez 24 godziny w temperaturze optymalnej dla badanego gatunku bakterii. Po inkubacji pozytywny wynik reakcji jest widoczny na płytce diagnostycznej w postaci fioletowego zabarwienia, które powstaje wskutek zajścia reakcji red-ox. Stopień zmętnienia zawiesiny w każdej ze studzienek mierzony jest spektrofotometrycznie w czytniku i zapisywany dodatko- wo również w postaci wyniku dodatniego, ujemnego lub pośredniego. W ten sposób powstaje specyficzny dla badanego izolatu bakterii profil metaboliczny, który przy pomocy algorytmu systemu Biolog można porównać do blisko 2 tysięcy innych profili metabolicznych zawartych w bazie danych systemu.

\section{Wyniki i dyskusja / Results and discussion}

\section{Pozyskiwanie izolatów bakteryjnych}

Wszystkie pozyskane izolaty bakteryjne, z wyszczególnieniem pochodzenia każdego $\mathrm{z}$ nich, przedstawiono w tabeli 1. Ogółem pozyskano i przebadano 109 izolatów bakteryjnych.

\section{Charakterystyka biochemiczna}

Istnieje wiele cech biochemicznych bakterii, które wywierają korzystny wpływ na wzrost roślin. W pracy podjęto badania pięciu wybranych cech biochemicznych, których związek ze wzrostem długości pędów oraz zwiększeniem ilości ekstraktów korzeniowych został naukowo udowodniony (Ghodsalavi i wsp. 2013). Na podstawie przeprowadzonych testów określono, które $\mathrm{z}$ badanych izolatów wykazują właściwości biochemiczne potencjalnie korzystnie wpływające na wzrost roślin. Wyniki te przedstawiono w tabeli 1 . Wśród badanych izolatów nie zanotowano silnego natężenia reakcji biochemicznej na pożywce CMC (3 i 4 w skali 0-4), wskazującego na obecność enzymu celulazy. Średnią aktywność tego enzymu (2) zanotowano jedynie dla izolatów pochodzących z: cebuli (Ce06, Ce08), pomidora (NB2-2), ogórka (O-111), korzenia soi (K15) i kukurydzy (KNB). Dla kolejnych 10 (spośród 109 badanych) izolatów zanotowano występowanie niskiego natężenia tej reakcji (1) (tab. 1). Występowanie izolatów silnie rozpuszczających fosforany nieorganiczne na pożywce PVK (3 lub 4) zanotowano w: cebuli (Ce02, $\mathrm{Ce} 04, \mathrm{Ce} 08 \mathrm{~b}, \mathrm{Ce} 08 \mathrm{c}$, CeM01, CeM03), kalafiorze (F3), pomidorze (NB1, DRNB2-2, DRNB, DRNB43), soi (L11, L12, K16, K18, $\mathrm{KT} 1, \mathrm{KT} 2, \mathrm{KT} 3)$, pomidorze (ZF1, ZF2, ZF3), ziemniaku (Z10) i kukurydzy (PB04-PB08, KG2, KNA, KNB) oraz W roślinach ozdobnych: pelargonii (Pel1), poinsecji (Poinset.K3, Poinset.K4), prymuli (Prym3) i róży (R1, R2A, R8). Wymienionym izolatom towarzyszyła grupa 31 (spośród 109) badanych izolatów wykazujących średnią lub niską zdolność (2 lub 1) do rozpuszczania fosforanów nieorganicznych (tab. 1). W przypadku pożywki CAS, na której badana była zdolność do wytwarzania sideroforów przez bakterie, nie zanotowano pozytywnego wyniku dla żadnego $\mathrm{z}$ badanych izolatów bakteryjnych. Natomiast na pożywce SM obecność pyowerdyny, fluorescencyjnego sideroforu produkowanego głównie przez bakterie rodzaju Pseudomonas, zanotowano dla izolatów pochodzących z: cebuli (Ce08) i soi (K15). W tym przypadku również zanotowano obecność populacji izolatów wykazujących średnie lub niskie natężenie tej cechy (11 spośród 109) (tab. 1). Silne nasilenie reakcji biochemicznej oznaczającej obecność enzymu lipazy zanotowano dla izolatów pochodzących z: cebuli (Ce01, Ce08a, Ce08b, Ce08c), soi 
(Ł21, L23, K12, K15, K17, K18). Dla tej cechy biochemicznej również zanotowano występowanie izolatów wykazujących średnie lub niskie nasilenie badanej cechy (32 spośród 109) (tab. 1). Obecność enzymu proteazy na pożywce SMA wyraźnie zaznaczona była dla izolatów pozyskanych z: cebuli (Ce05, Ce07, Ce08a, Ce08b, Ce08c), pomidora (DRNB, DRNB43), soi (K15, K18), ziemniaka (Z02, Z05, Z06) i kukurydzy (PB03). Wymienionym izolatom towarzyszyło 39 (spośród 109 badanych) kolejnych izolatów wykazujących średnie lub niskie nasilenie tej cechy (tab. 1).

Wśród pozyskanych i badanych 109 izolatów bakterii endofitycznych szereg izolatów wykazywało duże lub bardzo duże nasilenie badanej cechy biochemicznej opisane wynikiem 3 lub 4 w pięciopunktowej skali. Wysoką zdolność do rozpuszczania fosforanów na pożywce PVK wykazywało $35 \%$ badanych izolatów endofitycznych. Kolejne 2\% izolatów wytwarzało fluoryzujący w świetle UV siderofor - pyowerdynę, 9\% miało zdolność wytwarzania lipazy, a $14 \%$ proteazy (tab. 2). Badane izolaty nie wykazywały natomiast wysokiego nasilenia badanych cech biochemicznych: obecności enzymu celulazy (pożywka CMC) i zdolności do produkcji sideroforów (CAS) (tab. 2). Izolatom wykazującym duże nasilenie badanej cechy towarzyszyła populacja bakterii wykazujących średnie lub niskie natężenie badanej cechy, opisane w testach jako 1 lub 2. Słabe nasilenie produkcji enzymu celulazy wykazywało $9 \%$ badanych izolatów, rozpuszczalność fosforanów nieorganicznych na pożywce PVK wykazywało 28\% izolatów, kolejne 10\% wykazywało słabą zdolność do produkcji fluorescencyjnego sideroforu (SMA), 29\% produkowało w niskim nasileniu lipazę, a aż 36\% proteazę. Po zsumowaniu liczby izolatów wykazujących daną cechę biochemiczną okazuje się, że najpowszechniej wykazywaną cechą wśród badanych izolatów jest zdolność do rozpuszczania fosforanów nieorganicznych na pożywce PVK (63\% izolatów), zdolność do produkcji proteazy (49\%) oraz lipazy (39\%). Wytwarzanie celulazy i pyowerdyny oscylowało $\mathrm{w}$ granicach $10 \%$ (tab. 2). Wartości procentowe (i liczby) podane w tabeli 2. nie sumują się do 100 , ponieważ część izolatów wykazuje jednocześnie kilka (nawet do 5) z 6 badanych cech biochemicznych, jak np. izolat K15 (tab. 1).

\section{Identyfikacja bakterii}

Do identyfikacji wybranych izolatów bakteryjnych zastosowano system BIOLOG GEN III. System ten opracowano pierwotnie $\mathrm{z}$ myślą o identyfikacji bakterii chorobotwórczych dla ludzi, jednakże został on przez wielu badaczy oceniony i zastosowany do identyfikacji bakterii patogenicznych dla roślin oraz bakterii środowiskowych (Klingler i wsp. 1992; Konopka i wsp. 1998; Cottyn i wsp. 2001; Emerson i wsp. 2008; Marek-Kozaczuk i wsp. 2014). System BIOLOG GEN III stosowano również $\mathrm{W}$ identyfikacji populacji bakterii związanych z siewkami ryżu, w warunkach tropikalnych, w przypadkach kiedy zawodziła identyfikacja przy pomocy analizy kwasów thuszczowych (Fame) (Cottyn i wsp. 2001). Należy pamiętać, że wyniki identyfikacji uzyskane przy pomocy wyłącznie systemu BIOLOG GEN III należy traktować jako wstępną identyfikację, którą należałoby

Tabela 1. Charakterystyka biochemiczna izolatów bakteryjnych pozyskanych z roślin

Table 1. Biochemical characterization of selected bacterial isolates obtained from plant hosts

\begin{tabular}{|c|c|c|c|c|c|c|c|c|c|}
\hline \multirow{2}{*}{$\begin{array}{l}\text { Lp. } \\
\text { No. }\end{array}$} & \multirow{2}{*}{$\begin{array}{l}\text { Identyfikacja } \\
\text { Identification }\end{array}$} & \multirow{2}{*}{$\begin{array}{l}\text { Gospodarz } \\
\text { Host }\end{array}$} & \multirow{2}{*}{$\begin{array}{l}\text { Izolat } \\
\text { Isolate }\end{array}$} & \multicolumn{6}{|c|}{ Pożywka - Medium } \\
\hline & & & & $\mathrm{CMC}$ & PVK & CAS & SM & LP & SMA \\
\hline 1 & 2 & 3 & 4 & 5 & 6 & 7 & 8 & 9 & 10 \\
\hline 1 & Pantoea ananatis & cebula-onion & $\mathrm{Ce} 01$ & 0 & 1 & 0 & 0 & 3 & 3 \\
\hline 2 & Rahnella aquatilis & cebula - onion & $\mathrm{Ce} 02$ & 0 & 3 & 0 & 0 & 0 & 0 \\
\hline 3 & Pseudomonas fluorescens & cebula - onion & $\mathrm{Ce} 03$ & 0 & 1 & 0 & 1 & 1 & 1 \\
\hline 4 & Enterobacter amnigenus & cebula - onion & $\mathrm{Ce} 04$ & 0 & 3 & 0 & 0 & 0 & 0 \\
\hline 5 & Serratia plymuthica & cebula - onion & $\mathrm{Ce} 05$ & 0 & 1 & 0 & 0 & 2 & 3 \\
\hline 6 & Klebsiella oxytoca & cebula - onion & $\mathrm{Ce} 06$ & 2 & 2 & 0 & 0 & 0 & 0 \\
\hline 7 & Serratia liquefaciens & cebula-onion & $\mathrm{Ce} 07$ & 0 & 2 & 0 & 0 & 2 & 3 \\
\hline 8 & Serratia liquefaciens & cebula - onion & $\mathrm{Ce} 08 \mathrm{a}$ & 2 & 2 & 0 & 0 & 3 & 4 \\
\hline 9 & Klebsiella oxytoca & cebula - onion & $\mathrm{Ce} 08 \mathrm{~b}$ & 0 & 3 & 0 & 3 & 3 & 4 \\
\hline 10 & Pseudomonas aeruginosa & cebula-onion & $\mathrm{Ce} 08 \mathrm{c}$ & 0 & 3 & 0 & 2 & 3 & 4 \\
\hline 11 & Enterobacter aerogenes & cebula - onion & CeB01A & 0 & 2 & 0 & 0 & 0 & 0 \\
\hline 12 & Pseudomonas putida & cebula - onion & CeB01B & 0 & 2 & 0 & 0 & 0 & 0 \\
\hline 13 & Pantoea agglomerans & cebula - onion & CeM01 & 0 & 3 & 0 & 0 & 1 & 0 \\
\hline 14 & Pseudomonas putida & cebula - onion & CeM02 & 0 & 2 & 0 & 0 & 0 & 0 \\
\hline 15 & Pantoea agglomerans & cebula - onion & CeM03 & 1 & 3 & 0 & 0 & 1 & 0 \\
\hline 16 & Pseudomonas putida & cebula - onion & CeM04 & 0 & 2 & 0 & 0 & 0 & 0 \\
\hline 17 & Pantoea sp. & kalafior - couliflower & F3 & 0 & 4 & 0 & 0 & 0 & 2 \\
\hline
\end{tabular}




\begin{tabular}{|c|c|c|c|c|c|c|c|c|c|}
\hline 1 & 2 & 3 & 4 & 5 & 6 & 7 & 8 & 9 & 10 \\
\hline 18 & nie badano - not tested & kalafior - couliflower & W3 & 0 & 0 & 0 & 0 & 1 & 1 \\
\hline 19 & Pseudomonas syringae pv. glicynea & pomidor - tomato & NB1 & 0 & 3 & 0 & 0 & 0 & 2 \\
\hline 20 & nie badano - not tested & pomidor - tomato & NB1-1 & 0 & 0 & 0 & 0 & 0 & 2 \\
\hline 21 & Pseudomonas fragi & pomidor - tomato & NB1-2 & 0 & 0 & 0 & 0 & 0 & 1 \\
\hline 22 & nie badano - not tested & pomidor - tomato & NB1-3 & 0 & 0 & 0 & 0 & 0 & 2 \\
\hline 23 & nie badano - not tested & pomidor - tomato & NB2-1 & 0 & 2 & 0 & 0 & 0 & 0 \\
\hline 24 & nie badano - not tested & pomidor - tomato & NB2-2 & 2 & 0 & 0 & 0 & 0 & 2 \\
\hline 25 & nie badano - not tested & pomidor - tomato & DRNB2-1 & 1 & 0 & 0 & 0 & 0 & 2 \\
\hline 26 & nie badano - not tested & pomidor - tomato & DRNB2-2 & 0 & 3 & 0 & 0 & 0 & 0 \\
\hline 27 & nie badano - not tested & pomidor - tomato & DRNB & 1 & 3 & 0 & 0 & 2 & 3 \\
\hline 28 & nie badano - not tested & pomidor - tomato & DRNB43 & 1 & 3 & 0 & 0 & 2 & 3 \\
\hline 29 & nie badano - not tested & ogórek - cucumber & $\mathrm{O}-1$ & 0 & 0 & 0 & 0 & 0 & 2 \\
\hline 30 & Pseudomonas putida & ogórek - cucumber & O-111 & 2 & 2 & 0 & 0 & 0 & 0 \\
\hline 31 & nie badano - not tested & ogórek - cucumber & O-512 & 0 & 0 & 0 & 0 & 0 & 2 \\
\hline 32 & nie badano - not tested & ogórek - cucumber & $\mathrm{O}-32$ & 0 & 0 & 0 & 0 & 0 & 1 \\
\hline 33 & nie badano - not tested & ogórek - cucumber & O-33 & 0 & 0 & 0 & 0 & 0 & 1 \\
\hline 34 & nie badano - not tested & ogórek - cucumber & O-81 & 0 & 0 & 0 & 0 & 0 & 0 \\
\hline 35 & nie badano - not tested & ogórek - cucumber & $\mathrm{O}-82$ & 0 & 0 & 0 & 0 & 0 & 0 \\
\hline 36 & nie badano - not tested & soja - łodyga - soy - stalk & $Ł 11$ & 0 & & 0 & 0 & 1 & 0 \\
\hline 37 & nie badano - not tested & soja - łodyga - soy - stalk & Ł12 & 0 & 0 & 0 & 0 & 1 & 0 \\
\hline 38 & nie badano - not tested & soja - łodyga - soy - stalk & $Ł 13$ & 0 & 0 & 0 & 0 & 0 & 0 \\
\hline 39 & Serratia fonticola & soja - łodyga - soy - stalk & $Ł 21 \mathrm{a}$ & 0 & 2 & 0 & 0 & 3 & 0 \\
\hline 40 & Enterobacter cloaceae subsp. cloaceae & soja - łodyga - soy - stalk & $Ł 21 b$ & 0 & 2 & 0 & 0 & 0 & 2 \\
\hline 41 & nie badano - not tested & soja - łodyga - soy - stalk & $Ł 22$ & 0 & 0 & 0 & 0 & 1 & 2 \\
\hline 42 & nie badano - not tested & soja - łodyga - soy - stalk & $Ł 23$ & 0 & 1 & 0 & 0 & 1 & 2 \\
\hline 43 & nie badano - not tested & soja - łodyga - soy - stalk & $Ł 24$ & 0 & 0 & 0 & 0 & 1 & 0 \\
\hline 44 & nie badano - not tested & soja - liść - soy - leaf & L11 & 0 & 3 & 0 & 0 & 0 & 1 \\
\hline 45 & nie badano - not tested & soja - liść - soy - leaf & L12 & 0 & 3 & 0 & 0 & 2 & 2 \\
\hline 46 & nie badano - not tested & soja - liść - soy - leaf & L21 & 0 & 1 & 0 & 0 & 1 & 1 \\
\hline 47 & nie badano - not tested & soja - liść - soy - leaf & $\mathrm{L} 22$ & 0 & 2 & 0 & 0 & 1 & 2 \\
\hline 48 & nie badano - not tested & soja - liść - soy - leaf & L23 & 0 & 0 & 0 & 1 & 4 & 1 \\
\hline 49 & nie badano - not tested & soja-korzeń - soy - root & K11 & 0 & 0 & 0 & 0 & 1 & 0 \\
\hline 50 & nie badano - not tested & soja - korzeń - soy - root & K12 & 1 & 0 & 0 & 0 & 3 & 1 \\
\hline 51 & nie badano - not tested & soja - korzeń - soy - root & K13 & 0 & 0 & 0 & 1 & 0 & 1 \\
\hline 52 & nie badano - not tested & soja - korzeń - soy - root & K14 & 0 & 0 & 0 & 0 & 2 & 2 \\
\hline 53 & Serratia odorifera & soja-korzeń - soy - root & $\mathrm{K} 15$ & 2 & 1 & 0 & 4 & 3 & 3 \\
\hline 54 & nie badano - not tested & soja - korzeń - soy - root & K16 & 0 & 3 & 0 & 0 & 1 & 1 \\
\hline 55 & nie badano - not tested & soja - korzeń - soy - root & K17 & 0 & 0 & 0 & 0 & 3 & 1 \\
\hline 56 & Klebsiella oxytoca & soja - korzeń - soy - root & K18 & 0 & 3 & 0 & 1 & 3 & 3 \\
\hline 57 & Pseudomonas savastanoi & soja - soy & KT1 & 0 & 3 & 0 & 0 & 0 & 2 \\
\hline 58 & Pseudomonas viridiflava & soja - soy & KT2 & 0 & 3 & 0 & 0 & 0 & 0 \\
\hline 59 & Enterobacter aerogenes & soja-soy & KT3 & 0 & 3 & 0 & 0 & 0 & 0 \\
\hline 60 & Pseudomonas putida & pomidor - tomato & ZF1 & 0 & 3 & 0 & 0 & 0 & 0 \\
\hline 61 & brak ID - no ID & pomidor - tomato & ZF2 & 1 & 3 & 0 & 0 & 0 & 0 \\
\hline 62 & Pseudomonas putida & pomidor - tomato & ZF3 & 0 & 3 & 0 & 0 & 0 & 0 \\
\hline 63 & $\begin{array}{l}\text { Herbaspirillum huttiense } \\
\text { subsp. huttiense }\end{array}$ & pomidor - tomato & ZF4 & 0 & 0 & 0 & 0 & 0 & 0 \\
\hline 64 & nie badano - not tested & ziemniak - potato & Z01 & 0 & 0 & 0 & 0 & 0 & 0 \\
\hline 65 & nie badano - not tested & ziemniak - potato & $\mathrm{Z} 02$ & 1 & 2 & 0 & 1 & 0 & 3 \\
\hline
\end{tabular}




\begin{tabular}{|c|c|c|c|c|c|c|c|c|c|}
\hline 1 & 2 & 3 & 4 & 5 & 6 & 7 & 8 & 9 & 10 \\
\hline 66 & nie badano - not tested & ziemniak - potato & $\mathrm{Z} 03$ & 0 & 2 & 0 & 0 & 0 & 0 \\
\hline 67 & nie badano - not tested & ziemniak - potato & $\mathrm{Z} 05$ & 0 & 2 & 0 & 0 & 1 & 3 \\
\hline 68 & Serratia plymuthica & ziemniak - potato & Z06 & 0 & 2 & 0 & 0 & 2 & 3 \\
\hline 69 & nie badano - not tested & ziemniak - potato & Z09 & 0 & 1 & 0 & 1 & 1 & 1 \\
\hline 70 & nie badano - not tested & ziemniak - potato & $\mathrm{Z10}$ & 0 & 3 & 0 & 0 & 0 & 0 \\
\hline 71 & Pseudomonas tolaasi & kukurydza - maize & PB01 & 0 & 1 & 0 & 1 & 1 & 1 \\
\hline 72 & Pseudomonas straminea & kukurydza - maize & PB02 & 0 & 1 & 0 & 0 & 0 & 0 \\
\hline 73 & Xanthomonas sp. & kukurydza - maize & PB03 & 1 & 0 & 0 & 0 & 0 & 3 \\
\hline 74 & nie badano - not tested & kukurydza - maize & PB04 & 0 & 3 & 0 & 0 & 0 & 0 \\
\hline 75 & Pantoea agglomerans & kukurydza - maize & PB05 & 0 & 3 & 0 & 0 & 2 & 0 \\
\hline 76 & brak ID - no ID & kukurydza - maize & PB06 & 0 & 3 & 0 & 0 & 0 & 0 \\
\hline 77 & Pantoea agglomerans & kukurydza - maize & PB07 & 0 & 3 & 0 & 0 & 1 & 0 \\
\hline 78 & Pantoea agglomerans & kukurydza - maize & PB08 & 0 & 3 & 0 & 0 & 1 & 0 \\
\hline 79 & $\begin{array}{l}\text { Enterobacter cloaceae } \\
\text { subsp. dissolvens }\end{array}$ & kukurydza - maize & KG1 & 0 & 1 & 0 & 0 & 0 & 0 \\
\hline 80 & $\begin{array}{l}\text { Enterobacter cloaceae } \\
\text { subsp. dissolvens }\end{array}$ & kukurydza - maize & KG2 & 0 & 3 & 0 & 0 & 0 & 0 \\
\hline 81 & $\begin{array}{l}\text { Enterobacter cloaceae } \\
\text { subsp. dissolvens }\end{array}$ & kukurydza - maize & KNA & 0 & 3 & 0 & 0 & 0 & 0 \\
\hline 82 & Pseudomonas fulva & kukurydza - maize & KNB & 2 & 3 & 0 & 0 & 0 & 0 \\
\hline 83 & nie badano - not tested & pelargonia - geranium & P1-Pel & 0 & 0 & 0 & 0 & 0 & 0 \\
\hline 84 & nie badano - not tested & pelargonia - geranium & P2-Pel & 0 & 0 & 0 & 0 & 0 & 0 \\
\hline 85 & nie badano - not tested & pelargonia - geranium & Pel 1 & & 3 & 0 & 0 & 0 & 2 \\
\hline 86 & $\begin{array}{l}\text { Pseudomonas chloraphis } \\
\text { subsp. aurantiaca }\end{array}$ & poinsecja - poinsettia & Poinset.K1 & 0 & 0 & 0 & 1 & 1 & 0 \\
\hline 87 & Pseudomans fluorescens & poinsecja - poinsettia & Poinset.K2 & 0 & 0 & 0 & 0 & 1 & 0 \\
\hline 88 & Pseudomans fluorescens & poinsecja - poinsettia & Poinset.K3 & 0 & 3 & 0 & 0 & 0 & 1 \\
\hline 89 & Raoultella terrigena & poinsecja - poinsettia & Poinset.K4 & 0 & 3 & 0 & 0 & 0 & 0 \\
\hline 90 & nie badano - not tested & kalia - calla & Kal 1 & 0 & 0 & 0 & 0 & 0 & 1 \\
\hline 91 & nie badano - not tested & kalia - calla & Kal 3 & 0 & 0 & 0 & 0 & 1 & 1 \\
\hline 92 & nie badano - not tested & kalia - calla & Kal 5 & 0 & 0 & 0 & 0 & 1 & 1 \\
\hline 93 & nie badano - not tested & kalia - calla & Kal 6 & 0 & 0 & 0 & 0 & 0 & 2 \\
\hline 94 & nie badano - not tested & kalia - calla & Kal 8 & 0 & 2 & 0 & 0 & 0 & 1 \\
\hline 95 & nie badano - not tested & prymula - primrose & Prym 3 & 0 & 3 & 0 & 0 & 0 & 0 \\
\hline 96 & nie badano - not tested & róża - rose & $\mathrm{R} 1$ & 0 & 3 & 0 & 0 & 0 & 0 \\
\hline 97 & nie badano - not tested & róża - rose & $\mathrm{R} 2$ & 0 & 0 & 0 & 0 & 2 & 1 \\
\hline 98 & nie badano - not tested & róża-rose & $\mathrm{R} 2 \mathrm{~A}$ & 0 & 3 & 0 & 0 & 2 & 1 \\
\hline 99 & nie badano - not tested & róża - rose & R3 & 0 & 1 & 0 & 0 & 0 & 0 \\
\hline 100 & nie badano - not tested & róża - rose & R4 & 0 & 0 & 0 & 0 & 0 & 0 \\
\hline 101 & Rahnella aquatilis & róża - rose & R5 & 1 & 1 & 0 & 0 & 1 & 3 \\
\hline 102 & nie badano - not tested & róża - rose & R6 & 1 & 2 & 0 & 0 & 0 & 0 \\
\hline 103 & nie badano - not tested & róża-rose & R6A & 0 & 0 & 0 & 0 & 0 & 0 \\
\hline 104 & nie badano - not tested & róża - rose & R7 & 0 & 0 & 0 & 0 & 0 & 0 \\
\hline 105 & nie badano - not tested & róża - rose & R7A & 0 & 0 & 0 & 0 & 0 & 0 \\
\hline 106 & nie badano - not tested & róża - rose & $\mathrm{R} 7 \mathrm{~B}$ & 0 & 0 & 0 & 0 & 0 & 0 \\
\hline 107 & Pseudomonas fluorescens & róża - rose & $\mathrm{R} 8$ & 1 & 3 & 0 & 2 & 0 & 0 \\
\hline 108 & nie badano - not tested & róża-rose & R8A & 0 & 2 & 0 & 2 & 0 & 0 \\
\hline 109 & nie badano - not tested & róża-rose & $\mathrm{R} 8 \mathrm{~B}$ & 0 & 0 & 0 & 0 & 0 & 0 \\
\hline
\end{tabular}

brak ID - oznacza brak identyfikacji przy pomocy systemu BIOLOG GEN III - no ID - BIOLOG GEN III system was not able to identify the tested isolate 
Tabela 2. Podsumowanie liczbowe wyników charakterystyki biochemicznej izolatów bakteryjnych pozyskanych z roślin Table 2. The summary of results of biochemical characterization of tested bacterial isolates obtained from plants

\begin{tabular}{|c|c|c|c|}
\hline \multirow{2}{*}{$\begin{array}{l}\text { Nazwa pożywki } \\
\text { Medium name }\end{array}$} & \multicolumn{3}{|c|}{$\begin{array}{c}\text { Natężenie cechy w skali od } 0 \text { do } 4 \\
\text { Intensity of the tested quality from } 0 \text { to } 4\end{array}$} \\
\hline & $1-2$ & $3-4$ & razem - total \\
\hline $\mathrm{CMC}$ & $\begin{array}{c}10 \mathrm{ze}-\text { of the } 109 \\
{[9,17 \%]}\end{array}$ & $\begin{array}{c}0 \mathrm{ze}-\text { of the } 109 \\
{[0 \%]}\end{array}$ & $\begin{array}{c}10 \mathrm{ze}-\text { of the } 109 \\
{[9,17 \%]}\end{array}$ \\
\hline PVK & $\begin{array}{c}31 \mathrm{ze}-\text { of the } 109 \\
{[28,44 \%]}\end{array}$ & $\begin{array}{c}38 \mathrm{ze}-\text { of the } 109 \\
{[34,68 \%]}\end{array}$ & $\begin{array}{c}69 \mathrm{ze}-\text { of the } 109 \\
{[63,3 \%]}\end{array}$ \\
\hline CAS & $\begin{array}{c}0 \mathrm{ze}-\text { of the } 109 \\
{[0 \%]}\end{array}$ & $\begin{array}{c}0 \mathrm{ze}-\text { of the } 109 \\
{[0 \%]}\end{array}$ & $\begin{array}{c}0 \mathrm{ze}-\text { of the } 109 \\
{[0 \%]}\end{array}$ \\
\hline $\mathrm{SM}$ & $\begin{array}{c}11 \mathrm{ze}-\text { of the } 109 \\
{[10,09 \%]}\end{array}$ & $\begin{array}{c}2 \mathrm{ze}-\text { of the } 109 \\
{[1,83 \%]}\end{array}$ & $\begin{array}{c}13 \mathrm{ze}-\text { of the } 109 \\
{[11,93 \%]}\end{array}$ \\
\hline LP & $\begin{array}{c}32 \mathrm{ze}-\text { of the } 109 \\
{[29,36 \%]}\end{array}$ & $\begin{array}{c}10 \mathrm{ze}-\text { of the } 109 \\
{[9,17 \%]}\end{array}$ & $\begin{array}{c}42 \mathrm{ze}-\text { of the } 109 \\
{[38,53 \%]}\end{array}$ \\
\hline SMA & $\begin{array}{c}39 \mathrm{ze}-\text { of the } 109 \\
{[35,78 \%]}\end{array}$ & $\begin{array}{c}15 \mathrm{ze}-\text { of the } 109 \\
{[13,76 \%]}\end{array}$ & $\begin{array}{c}53 \mathrm{ze}-\text { of the } 109 \\
{[48,62 \%]}\end{array}$ \\
\hline
\end{tabular}

CMC - carboxymethylcellulose sodium salt medium, PVK - Pikovskaya's medium, CAS - chrome azurol S medium, SM - succinate medium, LP - lipase production medium, SMA - skim milk agar
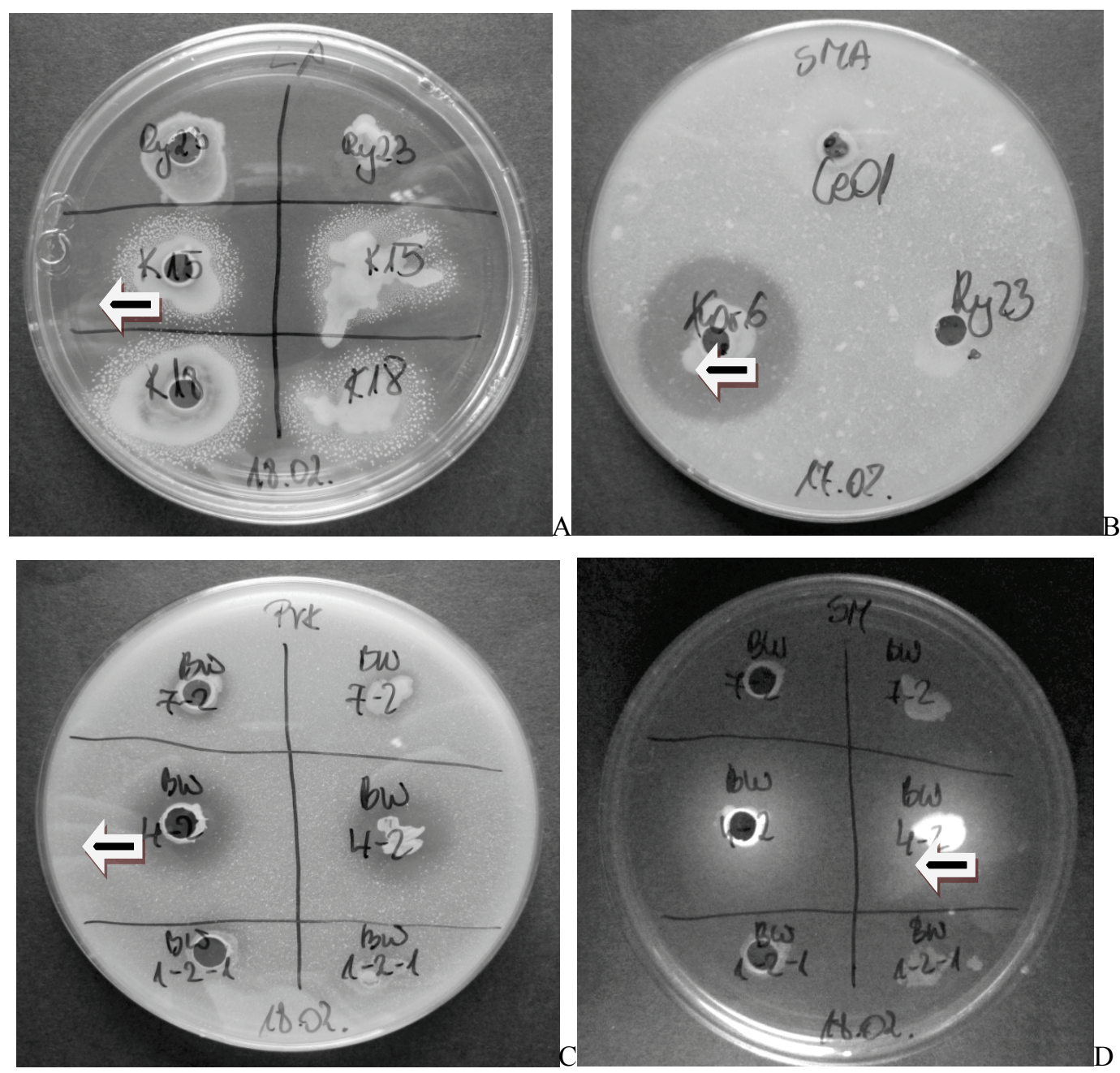

A - obecność lipazy - lipase production, B - obecność proteazy - protease production, C - rozpuszczalność fosforanów - phosphate solubility, D - obecność fluorescencyjnego sideroforu - pyowerdyny - the presence of pyoverdin, a fluorescent siderophore

Strzałki wskazują wynik dodatni - Arrows show positive result

Rys. 1. Przykłady dodatnich wyników reakcji biochemicznych obserwowanych na pożywkach mikrobiologicznych użytych w doświadczeniu

Fig. 1. Examples of positive results of biochemical reactions observed on microbiological media used in the experiment 
potwierdzić inną metodą diagnostyczną. O wyborze systemu BIOLOG GEN III zadecydował jednak fakt, że nawet w przypadku potencjalnie błędnej identyfikacji, uzyskany wynik ma znaczenie sam w sobie jako obszerna charakterystyka biochemiczna izolatu obejmująca aż 95 cech biochemicznych.

Analizie z wykorzystaniem systemu BIOLOG GEN III poddano izolaty bakteryjne, wybrane spośród dotychczas badanych, które wykazywały najbardziej obiecujące wyniki, czyli najsilniejsze reakcje na badanych pożywkach oraz część izolatów losowo wybranych, niewykazujących takich właściwości, w celu lepszego scharakteryzowania badanej populacji bakterii. Wszystkie wyniki badania przy pomocy systemu BIOLOG GEN III zostały przedstawione w tabeli 1.

W przypadku bakterii roślinnych zjawisko powszechnego występowania zdolności do rozpuszczania fosforanów można tłumaczyć następującą zależnością. Rozpuszczanie fosforanów nieorganicznych w glebie przez PGPB czyni je dostępnymi dla roślin, co bezpośrednio stymuluje ich wzrost. Z kolei dobrze rozwinięta roślina może produkować więcej wydzielin korzeniowych, które jak wspomniano wcześniej, stanowią dla bakterii źródło pożywienia i działają, jak chemiczny atraktant. Stwierdzono, że niektóre z bakterii glebowych mogą przenikać do wnętrza korzenia i dawać początek nowej populacji endofitów (Compant i wsp. 2005) w łodydze, liściach, bulwach i innych organach (Gray i Smith 2005). Zdolność takich bakterii do kolonizacji nowych nisz ekologicznych może świadczyć o ich zdolności do selektywnej adaptacji w zmiennych niszach ekologicznych. W konsekwencji między bakterią a gospodarzem roślinnym tworzy się zależność oparta na wspólnych korzyściach. Zależność taka może być prawdopodobnym wytłumaczeniem tak powszechnego występowania $(63 \%)$ wśród badanych endofitów zdolności do rozpuszczania fosforanów nieorganicznych na pożywce PVK. Korzystne działanie bakterii wykazujących taką zdolność zostało potwierdzone doświadczalnie (Kannapiran i Ramkumar 2011; Sharma i wsp. 2011; Kelel i wsp. 2014). Uważa się również, że rozpuszczanie fosforanów przez bakterie i tworzenie na pożywkach stałych otoczek (stref halo) wokół kolonii, związane jest $\mathrm{z}$ uwalnianiem przez nie kwasów organicznych, takich jak: kwas cytrynowy, glioksalowy, jabłkowy, ketomasłowy, czy bursztynowy (Park i Kloepper 2000). Bakterie rozpuszczające nieorganiczne związki fosforu nie muszą być związane ze strefa korzeniową roślin. Mogą one występować w innych niszach ekologicznych, np. w środowisku wodnym (Przemieniecki i wsp. 2015).

Blisko połowa (49\%) badanych bakterii endofitycznych wykazywała zdolność do produkcji proteaz. Zdolność bakterii do ich wytwarzania była również badana dla bakterii glebowych (nie endofitów). W strefie ryzosferowej pszenicy stwierdzono występowanie bakterii Azospirillum brasiliense wykazujących zdolność do wytwarzania wielu enzymów, tj.: chitynazy, pektynazy, proteazy, fosfatazy, pektynazy i lipazy (Radif i Hassan 2014). Obecność bakterii produkujących fosfatazy oraz inne enzymy hydrolityczne w glebie, ma zdecydowanie pozytywny wpływ na wzrost roślin. Stwierdzono, że na aktywność tych enzymów bakteryjnych może mieć wpływ wiele czynników, tj.: skład chemiczny gleby i jej odczyn. Fosfataza bakteryjna ma szczególne znaczenie dla wzrostu roślin w glebach kwaśnych (Huang i wsp. 2011).

Trzy cechy wykazywane w największym nasileniu przez badane endofity, czyli: zdolność do rozpuszczania fosforanów nieorganicznych, zdolność do produkcji proteaz i lipaz wpływają korzystnie na zdolności adaptacyjne i przeżycie bakterii w glebie wśród innych mikroorganizmów. Produkcja proteaz i lipaz może stanowić mechanizm obronny przed innymi mikroorganizmami oraz umożliwiać zdobycie pokarmu w środowisku glebowym bogatym w substancje organiczne, np. pochodzące z rozkładu innych, martwych mikroorganizmów. Natomiast zdolność do rozpuszczania fosforanów nieorganicznych jest cechą preferowaną przez rośliny i wzmacnianą we wzajemnej zależności bakteria-roślina. Biorąc również pod uwagę opisaną zdolność niektórych bakterii glebowych do wnikania do wnętrza rośliny i kolonizacji jej tkanek bez wywołania objawów chorobowych, można w ten sposób thumaczyć częste występowanie tych trzech cech biochemicznych w populacji endosymbiontów pochodzących $\mathrm{z}$ różnych gospodarzy roślinnych.

Wartym podkreślenia jest fakt, że oprócz izolatów wykazujących silne lub bardzo silne nasilenie reakcji na badaną cechę (3 i $4 \mathrm{w}$ skali od 0 do 4), na wszystkich (oprócz CAS) sprawdzanych pożywkach, stwierdzono grupę organizmów wykazujących średnie lub słabe nasilenie badanych reakcji (tab. 1). Jest to istotne, ponieważ w doświadczeniach laboratoryjnych zwraca się uwagę na izolaty wykazujące najsilniejsze reakcje, ponieważ z założenia należy wyselekcjonować takie, które w doświadczeniach będą dawały największy, najbardziej widoczny efekt oraz $\mathrm{z}$ których możliwe będzie przygotowanie dobrze działającego biopreparatu. Należy jednak pamiętać, że w warunkach naturalnych kumulatywny efekt działania wielu potencjalnie ,średnich” lub „słabych” szczepów, może być nie do przecenienia dla wzrostu roślin. Dlatego w praktyce rolniczej bardzo ważne jest utrzymanie dobrego stanu gleby, a w szczególności zróżnicowania i żywotności mikroorganizmów ją zasiedlających. Izolaty bakterii wykazujące w testach zróżnicowane nasilenie danej cechy mogą być również cenne dla nauki. Można je wykorzystać do porównań z innymi izolatami tego samego gatunku u których stwierdzono duże nasilenie badanej cechy. Przykładem mogą być izolaty: $\mathrm{Ce} 07$ i Ce08a należące do gatunku Serratia liquefaciens wykazujące różnice względem siebie pod kątem badanych cech biochemicznych (tab. 1). Na zjawisko różnego nasilenia danej cechy biochemicznej wspomagającej wzrost roślin, u różnych szczepów tego samego gatunku, nakłada się również oddziaływanie środowiska. Efekt jaki konkretna bakteria wywiera na roślinę może się zmieniać w zależności od zmiany warunków, np.: bakteria wspomagająca roślinę poprzez wiązanie azotu, czy fosforu nie spełni swojej funkcji, kiedy znaczne ilości nawozu dodane są sztucznie do gleby. Oprócz tego zaobserwowano, że poszczególne szczepy bakterii mogą oddziaływać na różne rośliny w odmienny sposób. Przykładowo Pseudomonas fluorescens (szczep BSP53a), zmutowany tak, by wykazy- 
wał nadprodukcję kwasu indolooctowego (indoleacetic acid - IAA), stymulował rozwój korzeni u czarnej porzeczki, natomiast hamował rozwój ścian komórkowych $\mathrm{w}$ korzeniach wiśni. Zjawisko to zinterpretowano $\mathrm{w}$ ten sposób, że poziom IAA w korzeniach czarnej porzeczki był suboptymalny, dlatego nastąpiła stymulacja wzrostu. Natomiast poziom IAA w korzeniach wiśni był optymalny, co przy dodatkowym IAA od bakterii, spowodowało zahamowanie ich rozwoju (Glick 2012). Dlatego należy brać pod uwagę mnogość czynników działających jednocześnie w środowisku naturalnym, w glebie, między bakterią i rośliną gospodarza, która może powodować, że wyniki eksperymentów będą się różniły od zakładanych.

PGPB produkujące siderofory odgrywają ważną rolę we wspomaganiu wzrostu roślin. Związki te wiążą żelazo ze środowiska, przez co staje się ono mniej dostępne dla patogenów, co pośrednio korzystnie wpływa na wzrost roślin (Alexander i Zeeberi 1991). Zdolność do wytwarzania sideroforów odnotowano u różnych gatunków rodzaju Bacillus (Gardner i wsp. 2004; Wilson i wsp. 2010). Cecha ta występuje u bakterii Gram-ujemnych (Pseudomonas sp.) oraz u Gram-dodatnich (Bacillus i Rhodococcus) (Tian i wsp. 2009). Obecnie znanych jest przeszło 500 różnych rodzajów sideroforów, spośród których dla 270 określono strukturę chemiczną (Boukhalfa i wsp. 2003). Siderofory produkowane są również przez bakterie endofityczne. Jasim i wsp. (2014) badali endofityczne izolaty pod kątem produkcji sideroforów przy użyciu agaru CAS. Zdolność do wytwarzania sideroforów stwierdzono u trzech endofitycznych izolatów: ZoB1 (Bacillus sp.), ZoB2 (Pseudomonas sp.) i ZoB3 (Stenotrophomonas sp.). Na tej samej pożywce wszystkie badane w tej pracy izolaty bakterii nie wykazały zdolności wytwarzania sideroforów. Stwierdzono jedynie zdolność do wytwarzania pyowerdyny w pojedynczych izolatach pochodzących z: cebuli, soi i róży (tab. 1).

Bakterie PGPB badane i zidentyfikowane w pracy należą do gatunków występujących powszechnie w środowisku naturalnym, mających zdolność do samodzielnego przeżycia w glebie, wodzie czy resztkach pożniwnych. Gatunki te często są polifagiczne i łatwo adaptują się do nowych środowisk. Przykładem takich bakterii są gatunki: Pantoea ananatis, Pantoea agglomerans i Enterobacter cloaceae subsp. dissolvens. Występują one powszechnie w środowisku naturalnym, przy czym część ich populacji jest niepatogeniczna, a część jest patogenami roślin (Paccola-Meirelles i wsp. 2001; Rodriguez i wsp. 2003; Hoffman i wsp. 2005; Goszczynska i wsp. 2007; MoralesValenzuela i wsp. 2007). Oprócz tego gatunki te są również oportunistycznymi patogenami u ludzi (De Baere i wsp. 2004; Rezzonico i wsp. 2009) oraz wykorzystuje się je do biologicznej ochrony roślin przed chorobami (Loper i wsp. 1993; Wright i wsp. 2001). Należy podkreślić, że w niniejszej pracy, żadna $\mathrm{z}$ roślin, $\mathrm{z}$ których pobierano tkanki albo spod których pobierano próbki gleby do izolacji bakterii, nie wykazywała objawów chorobowych.

Narastające obecnie w dużym tempie zanieczyszczenie i degradacja środowiska naturalnego przez działalność człowieka oraz rosnąca szybko populacja ludzka pogłębiająca ten efekt, sprawiają, że z bakteriami wspomagającymi wzrost roślin wiąże się coraz większe nadzieje. Świadczą o tym nieustannie prowadzone badania naukowe nad zastosowaniem PGPB w rolnictwie, ogrodnictwie (Lucy i wsp. 2004; Esitken 2011) i leśnictwie (Chanway 1997; Enebak i wsp. 1998; Ribeiro i Cardoso 2012).

\section{Wnioski / Conclusions}

1. Dla każdej z badanych cech biochemicznych (z wyjątkiem zdolności do produkcji enzymu celulazy) występuje grupa bakterii wykazujących silną reakcję na daną cechę oraz towarzysząca jej grupa bakterii wykazujących średnie lub słabe nasilenie tej cechy.

2. Między szczepami tego samego gatunku występują różnice metaboliczne pod względem badanych cech, mogące świadczyć o zdolności bakterii do adaptowania się do środowiska, które aktualnie zajmują. Badanie tych różnic może przyczynić się do lepszego poznania mechanizmów działania bakterii oraz pomóc zidentyfikować markery genetyczne kodujące cechy biochemiczne bakterii wspomagające wzrost roślin.

3. Badane i zidentyfikowane w pracy PGPB należą do gatunków powszechnie występujących w środowisku, stosunkowo odpornych na jego zmiany, mogących przeżywać w glebie i w wodzie oraz mających szeroki zakres gospodarzy. Świadczy to o ogromnym potencjale biochemicznym bakterii.

\section{Literatura / References}

Acea M.J., Moore C.R., Alexander M. 1988. Survival and growth of bacteria introduced into soil. Soil Biology and Biochemistry 20 (4): 509-515.

Alexander B.D., Zeeberi D.A. 1991. Use of chromazurol S to evaluate siderophore production by rhizosphere bacteria. Biology and Fertility of Soils 2: 39-54.

Boukhalfa H., Lack J., Reilly S.D., Hersman L., Neu M.P. 2003. Siderophore production and facilitated uptake of iron and plutonium in Pseudomonas putida. AIP Conference Procedings 673: 343-344.

Chanway C.P. 1997. Inoculation of tree roots with plant growth promoting soil bacteria: An emerging technology for reforestation. Forest Science 43 (1): 99-112(14).

Compant S., Duffy B., Nowak J., Clément C., Ait Barka E. 2005. Use of plant growth-promoting bacteria for biocontrol of plant diseases: principles, mechanisms of action, and future prospects. Applied and Environmental Microbiology 71 (9): 4951-4959.

Cottyn B., Regalado E., Lanoot B., De Cleene M., Mew T.W., Swings J. 2001. Bacterial populations associated with rice seed in the tropical environment. Phytopathology 91: 282-292.

De Baere T., Verhelst R., Labit C., Verschraegen G., Wauters G., Claeys G., Vaneechoutte M. 2004. Bacteremic infection with Pantoea ananatis. Journal of Clinical Microbiology 42: 4393-4395. 
Emerson D., Agulto L., Liu H., Liping L. 2008. Identifying and characterizing bacteria in an era of genomics and proteomics. BioScience 58 (10): 925-936.

Enebak S.A., Wei G., Kloepper J.W. 1998. Effects of plant growth-promoting rhizobacteria on loblolly and slash pine seedlings. Forest Science 44 (1): 139-144(6).

Esitken A. 2011. Use of Plant Growth Promoting Rhizobacteria in: Horticultural Crops. Chapter 8. p. 189-192. In: "Bacteria in Agrobiology: Crop Ecosystems" (D.K. Maheshwari, ed.). Springer-Verlag Berlin Heidelberg, 433 pp. DOI 10.1007/978-3-642$-18357-78$.

Gardner R.A., Kinkade R., Wang C., Phanstiel O. 2004. Total synthesis of petrobactin and its homologues as potential growth stimuli for Marinobacter hydrocarbonoclasticus, an oil-degrading bacteria. The Journal of Organic Chemistry 69: 3530-3537.

Ghodsalavi B., Ahmadzadeh M., Soleimani M., Madloo P.B., Taghizad-Farid R. 2013. Isolation and characterization of rhizobacteria and their effects on root extracts of Valeriana officinalis. Australian Journal of Crop Science 7 (3): 338-344.

Glick B.R. 1995. The enhancement of plant growth by free-living bacteria. Canadian Journal of Microbiology 41 (2): $109-117$.

Glick B.R. 2012. Plant growth-promoting bacteria: Mechanisms and applications. Hindawi Publishing Corpotation Scientifica. Volume 2012, Article ID963401, 15 pp. http://dx/doi.org/10.6064/2012/963401

Goszczynska T., Botha W.J., Venter S.N., Coutinho T.A. 2007. Isolation and identification of the causal agent of brown stalk rot, a new disease of maize in south Africa. Plant Disease 91: 711-718.

Gray E.J., Smith D.L. 2005. Intracellular and extracellular PGPR: commonalities and distinctions in the plant-bacterium signaling processes. Soil Biology and Biochemistry 37: 395-412.

Hankin L., Anagnostakis S.A. 1977. Solid media containing carboxymethylcellulose to detect Cx cellulase activity of micro-organisms. Journal of General Microbiology 98: 109-115.

Hoffman H., Stindl S., Ludwig W., Stumpf A., Mehlen A., Heesemann J., Monget D., Schleifer K.H., Roggenkamp A. 2005. Reassignment of Enterobacter dissolvens to Enterobacter cloaceae as Enterobacter cloaceae subsp. dissolvens comb. nov. and emended description of Enterobacter asburiae and Enterobacter kobei. Systematic and Applied Microbiology 28: 196-205.

Huang W., Liu J., Zhou G., Zhang D., Deng Q. 2011. Effect of precipitation on soil acid phosphatase activity in three successional forests in southern China. Biogeosciences 8: 1901-1910. DOI: 10.5194/bg-8-1901-2011.

Jasim B., Aswathy A.J., Jimtha J.C., Jyothis M., Radhakrishnan E.K. 2014. Isolation and characterization of plant growth promoting endophytic bacteria from the rhizome of Zingiber officinale. Biotechnology 4 (2): 197-204. DOI: 10.1007/s13205-013-0143-3.

Kannapiran E., Ramkumar V.S. 2011. Isolation of phosphate solubilizing bacteria from the sediments of Thondi coast, Palk Strait, Southeast coast of India. Annals of Biological Research 2 (5): 157-163. http://scholarsresearchlibrary.com/archive.html

Kelel M., Abera G., Yisma A., Molla B., Gebre N., Adugna T., Wessel G. 2014. Isolation of phosphate solubilizing bacteria from acacia tree rhizophere soil. Journal of Microbiology and Biotechnology Research 4 (5): 9-13. http://scholarsresearchlibrary.com/ archive.html

Klingler J.M., Stowe R.P., Obenhuber D.C., Groves T.O., Mishra S.K., Pierson D.L. 1992. Evaluation of the biolog automated microbial identification system. Applied and Environmental Microbiology 58 (6): 2089-2092.

Konopka A., Oliver L., Turcco R.F. 1998. The use of carbon substrate utilization patterns in environmental and ecological microbiology. Microbial Ecology 35 (2): 103-115.

Loper J.E., Ishimaru C.A., Carnegie S.R., Vanavichit A. 1993. Cloning and characterization of aerobactin biosynthesis genes of the biological control agent Enterobacter cloacae. Applied and Environmental Microbiology 59: 4189-4197.

Lucy M., Reed E., Glick B.R. 2004. Applications of free living plant growth-promoting rhizobacteria. Antonie van Leeuwenhoek 86: 1-25.

Marek-Kozaczuk M., Wielbo J., Pawlik A., Skorupska A. 2014. Nodulation competitiveness of Ensifer meliloti alfalfa nodule isolates and their potential for application as inoculants. Polish Journal of Microbiology 63 (4): 375-386.

Morales-Valenzuela G., Silva-Rojas H.V., Ochoa-Martínez D., Valadez-Moctezuma E., Alarcón-Zúńiga B., Zelaya-Molina L.X., Córdova-Téllez L., Mendoza-Onofre L., Vaquera-Huerta H., Carballo-Carballo A., Farfán-Gómez A., Ávila-Quezada G. 2007. First report of Pantoea agglomerans causing leaf blight and vascular wilt in maize and sorghum in Mexico. Plant Disease 91, p. 1365.

Paccola-Meirelles L.D., Ferreira A.S., Meirelles W.F., Marriel I.E., Castela C.R. 2001. Detection of a bacterium associated with a Leaf Spot Disease of maize in Brazil. Journal of Phytopathology 149: 275-279. DOI: 10.1046/j.1439-0434.2001.00614.x.

Park K.S., Kloepper J.W. 2000. Activation of PR-1a promoter by rhizobacteria which induce systemic resistance in tobacco against Pseudomonas syringae pv. tabaci. Biological Control 18: 2-9.

Przemieniecki S.W., Kurowski T.P., Karwowska A. 2015. Plant growth promoting potential of Pseudomonas sp. SP0113 isolated from potable water from a closed water well. Archives of Biological Science Belgrade 67 (2): 663-673.

Radif H.M., Hassan S.S. 2014. Detection of hydrolytic enzymes produced by Azospirillum brasiliense isolated from root soil. World Journal of Experimental Biosciences 2 (2): 36-40.

Rezzonico F., Smits T., Montesinos E., Frey J.E., Duffy B. 2009. Genotypic comparison of Pantoea agglomerans plant and clinical strains. BMC Microbiology 9: 204-208.

Ribeiro C.M., Cardoso E.J.B.N. 2012. Isolation, selection and characterization of root-associated growth promoting bacteria in Brazil Pine (Araucaria angustifolia). Microbiological Research 167: 69-78.

Rodriguez J.N., Yano T., Beriam L.O.S., Destefano S.A.L., Oliveira V.M., Rosato Y.B. 2003. Comparative RFLP-ITS analysis between Enterobacter cloaceae strains isolated from plants and clinical origin. Arquivos do Instituto Biológico 70: 367-372.

Rovira A.D. 1965. Interactions between plant roots and soil microorganisms. Annual Review of Microbiology 19: 241-266.

Sharma S., Kumar V., Tripathi R.B. 2011. Isolation of phosphate solubilizing microorganism (PSMs) from soil. Journal of Microbiological Biotechnology and Research 1 (2): 90-95. http://scholarsresearchlibrary.com/archive.html

Tian F., Ding Y., Zhu H., Yao L., Du B. 2009. Genetic diversity of siderophore-producing bacteria of tobacco rhizosphere. Brazilian Journal of Microbiology 40: 276-284.

Van Overbeek L.S., Van Elsas J.D. 1995. Root exudates-induced promoter activity in Pseudomonas fluorescens mutants in the wheat rhizosphere. Applied and Environmental Microbiology 61: 890-898.

Wilson M.K., Abergel R.J., Arceneaux J.E., Raymond K.N., Byers B.R. 2010. Temporal production of the two Bacillus anthracis siderophores, petrobactin and bacillibactin. Biometals 23: 129-134.

Wright S.A.I., Zumoff C.H., Schneider L., Beer S.V. 2001. Pantoea agglomerans strain EH318 produces two antibiotics that inhibit Erwinia amylovora in vitro. Applied and Environmental Microbiology 67 (1): 284-292. 